\title{
BRIEF GEOGRAPHICAL AND HISTORIC OVERVIEW OF TOURISM TRANSNATIONALIZATION
}

\author{
Denis USHAKOV* \\ Suan Sunandha Rajabhat University, International College, Bangkok, Thailand, e-mail: den_ushakov@nuos.pro
}

Volodymyr FEDORCHENKO

Kyiv University of Tourism, Economics and Law, Department of Theory and Practice of Tourism and Hospitality, Kyiv, Ukraine, e-mail: v.fedorchenko@uohk.com.cn

Nataliia FEDORCHENKO

Kyiv University of Tourism, Economics and Law, Department of Civil Law and Tourism Legislative Regulation, Kyiv, Ukraine, e-mail: Fedorchenko_nata@uohk.com.cn

\section{Viktoriia RYBACHOK}

Kyiv University of Tourism, Economics and Law, Department of Civil Law and Tourism Legislative Regulation, Kyiv, Ukraine PE “Ryzhy’s Law Bureau”, Kyiv, Ukraine, e-mail: Viktoriia.r@tanu.pro

Mikhail BAZHENOV

Kyiv University of Tourism, Economics and Law, Department of Civil Law and Tourism Legislative Regulation, Court of Cassation in the Supreme Court, Kyiv, Ukraine, e-mail: m-bazhenov@ tanu.pro

\begin{abstract}
Citation: Ushakov, D., Fedorchenko, V., Fedorchenko, N., Rybachok, V., \& Bazhenov, M. (2020). BRIEF GEOGRAPHICAL AND HISTORIC OVERVIEW OF TOURISM TRANSNATIONALIZATION. GeoJournal of Tourism and Geosites, 31(3), 1180-1185. https://doi.org/10.30892/gtg.31333-556
\end{abstract}

\begin{abstract}
Multimodality of the world tourism development stimulates rather asynchronous dynamics of transnationalization in the regions worldwide. It has also contributed to the formation of rather complex system in global production of tourism services. The aim of the article is to study the peculiarities of transnationalization processes in various countries of the world during different historical periods. The main research method was empirical, with the help to analyze the generations of transnational corporations. It was concluded that the current stage in transnationalization of tourism business demonstrates that the leading role already belongs to the tour operators which are financially most stable.
\end{abstract}

Key words: International market, scale effect, direct foreign investments, transnational corporations, synergy

$* \quad * \quad * \quad * \quad * \quad *$

\section{INTRODUCTION}

Transnationalization of tourism business started in the $1960 \mathrm{~s}$, that is, with a nearly 50 -year delay from the similar processes in industrial production and agriculture. The causes for this delayed inclusion of world tourism in transnationalization process es are quite obvious: the tourism sector as such started to form in the late 19th century, and only after two world wars it finally became a ttractive and profitable as a separate type of commercial activity and business. Thus, only much later after that its growing volumes became motivational enough to move enterprises to the transnational level of management.

One of the reasons why the tourism sector was belated in terms of transnationalization processes by at least fifty years was its low investment attractiveness and its resource base's inability to diversify. Relaxed management is hardly possible in the tourism business. Here logically arise the questions: what forms the foreign material \& technical basis in the tourism business? In what facilities abroad would transnational tourism business be interested to invest? Today the most common objects for international investments in tourism are tourist brands and associations of tourist agencies. Back in the middle of the 20th century even the most economically developed countries with a lot of interested investors hardly had any strong tourist brand or even a big tourist company with a more or le ss stable client base, while for developing economies the very phenomenon of tourism was still rather unusual. Thus, tourist compan ies of the mid 20th century were mostly investing in hotels and transport companies, which were logical and nearly the only option for them.

Transport companies of those days were often stronger (economically and in terms of marketing too) than majority of tourist firms. The former were concentrating their efforts on transportation of passengers and cargo delivery and thus had the minimum dependence upon tourist enterprises. Moreover, buying a hotel often meant certain limitation of activities for a new owner and thus narrower specialization, since a hotel enterprise, due to specificity of its material base, is hard to redesign or restructure.

Of course, a hotel can be rebuilt into an office center or into a standard residential unit, however, only in case it is situated in a convenient location (in downtown or near important crossroads, etc.). Resort hotels or hotels located near highways have very little chances for successful redesigning of activities. This is especially the case with rural resort areas, with their low numbers of local population and absence of industrial production. At the same time, hotel business always has rather high level of investment risks, especially when it comes to resort areas due to very limited opportunities for diversification and dangerously tight correlation between the efficiency of local assets' use and regional development in a certain area overall.

For all of these reasons, transnationalization processes in tourism sector overall and hospitality sector especially were always lagging behind similar processes in other economic sectors (Rudyk, 2000). Any tourist company, willing to move forward to the transnational level in its development and management, must be aware of high entry costs (including large investment volumes so that to purchase objects abroad, their modernization and upgrade so that to comply with the world standards of servicing). Moreover, significant spending would be needed not only for purchases and upgrade but also for further promotion campaigns at own, national tourist markets so that to guarantee itself the sufficient volumes of sales (Andreeva and Ushakov, 2016). On the other hand, a tourist company, already involved in

\footnotetext{
${ }^{*}$ Corresponding author
} 
transnationalization, bears the local risks quite intentionally and is able to develop alternative scenarios of sales (for example, a local hotel in some cases can rent out its spaces to local businesses, if the volume of tourists is not sufficient enough) (Karmanovskaya et al., 2020).

The latter partially explains why foreign investors prefer, in most cases, urban hotels first of all and are less interested in resorts or highways motels (the latter become an interesting option for international investors once tourist sector in a country is deve loped enough to guarantee high volumes of national and international tourists' circulation). Even a very tenuous analysis of foreign investments in hospitality industries worldwide clearly demonstrates that the initial interest of investors entering countries always concerns downtowns (in the capital city first of all) (Tulbayeva et al., 2017). Even though such entry is always very expensive for investors (real estate in a capital city is always much more expensive than real estate on a resort line), the overall level of foreign investment risk is significantly lower. First of all, the room occupancy rate in a capital city (or other big cities) is not subject to seasonality since such hotels are mostly business-oriented, thus hospitality sector in big cities is more dependent on the state of busines s development overall, rather on the rate of local tourism development. Secondly, in case of a business failure, any hotel downtown can easily become an office center or can be redesigned to become a fashionable housing unit, thus selling/renting out luxury apartments instead of rooms. Only after successful implementation of real estate project in a capital city or other large cities of a country foreign investors start considering the option of entering the real estate markets on the resort lines in the same country (Sayabaev et al., 2016).

\section{MATERIALS AND METHODS}

The historical method was used to study the main stages of the transnationalization of the tourism sector. The authors analyzed the characteristics and features of the functioning of tourist TNCs from their occurrence to the present. The transnationalization of tourism production has fundamentally changed the functioning mechanisms of leading industry institutions, which required the development of a scientific concept that would determine the reserves of the global competitiveness of tourism multinationals, which would determine the directions of economic expansion of transnational capital and form a methodological basis for predicting the interconnected processes of globalization and transnationalization of world tourism, as well as develop models response to them by private business and the state.

A transnational tourism business can be defined as a socio-economic phenomenon that depends not on national, but on external factors, the content and quantity of which are determined by the world community, whose members are related to each other in all spheres of public life, including economics, politics, ideology, culture, social sphere, ecology, safety. Under the conditions of transnationalization, environmental factors of the tourism market are conventionally classified as global and local, and the role of the former as determinants of the development of inbound tourism in the receptive region is more significant and significant.

The main components of the transnationalization of international tourism include expanding international economic ties in tourism production, increasing the internationalization of tourism production factors (by increasing direct and portfolio foreign investment, sharing knowledge and technologies, removing migration restrictions, popularizing distance education, etc.) the spread of transnational corporations in the tourism business, the characteristic features of which are interchangeability and interdependence of the organizational structure, orientation to information resources, and markets with a high level of consumption. An additional factor in the ac tualization of the search for a scientific definition of transnationalization of the tourism production process is the incre asing criticism of the activities of transnational corporations (TNCs) by the host states.

\section{RESULTS AND DISCUSSION}

\section{Business Motivation of Transnationalization Waves in Tourism and Hospitality Sectors}

Taking into account rather narrow specialization of resort hotels, their limited opportunities to switch business and also instability of tourist demand (for example, in case of income level fall or changing tourist preferences, etc.), it would be logical to assume transnational level of hospitality business can be economically feasible and profitable only in case TNC buys out not one hotel, but several hotels in different locations. This obviously means creation of a corporate hotel chain inside the TNC. Hotel chain is a joint business which is carried out and managed using common standards of servicing and under the same trademark. In most cases hotel chain is much more efficient in its management than separate hotel businesses, again, predominantly due to scale effect. Merging several hotels into a chain allows cutting the spending manifold, especially in terms of advertising and promotion, HR preparation and management, own standards' development and unique technologies' use. Hotel chains are also much more attractive from the investors' standpoint since chains are able to offer more tempting and more efficient schemes of cooperation for both investors themselves and their wide client base too (Kala et al., 2017; Dunets et al., 2019).

Establishment of an own hotel chain always requires high volumes of expenditures on the side of a founding corporation, while efficiency of local assets' use still depends more on the state of regional tourism development rather than on the capacities of a particular TNC (Savchuk, 2002). For this very reason, foreign investments come into hotel business only at a certain point of international tourism development in a country, once tourists' inflows become more or less stable and predictable.

First transnational deals in hotel business, interestingly, were not between a developed country and a developing one (for example, as it was often the case in transnational agricultural business) but between two developed economies. This was because international tourism of the previous century was developing primarily between already mature economies, often geographically close to each other. There were quite many reasons for this trend: transportation and communications were not developed enough yet, people still feared cultural differences and overall, the world was developing under the conditions of geopolitical bipolarity which did not contribute to tourism development at all. European countries which were the initiators and the pioneers of integration processes in tourism, themselves fitted all necessary criteria: they were geographically close to each other, their rates of economic development were rather similar, and they were functioning under conditions of trade liberalization and cultural homogeneity.

Thus, intra-European tourism provoked the emergence of European transnational companies in the sectors of tourism and hospitality. Another stimulus for hotel businesses' transnationalization was quick popularization and spread of franchising schemes. With the emergence of franchising, entry barriers for already large European hotel chains became nearly ground level when it came to other regions worldwide. Franchising means that there is no need for own significant investments. Moreover, risks of project failure are fully on the shoulders of a local franchisee, the owner of a local hotel. At the same time, franchising brings stable incomes for a hotel chain overall and strengthens its brand both regionally and worldwide. In the majority of cases we can observe a certain regularity: hotel chains, airline companies and large tourist enterprises from the countries which are traditional tourist donors (such as the UK, Germany, Nordic countries and also Belgium, Holland and France) were investing directly and heavily into hotel businesses located in popular destinations of European tourism - Italy, Spain, South of France, Greece and the like (Movsesyan, 2001). Within the tourism sector in its wider meaning, the leaders in transnationalization were hotels and airlines. First European airlines were quite strictly following the theory of related diversification, they were investing in other types of tourism activities (agent sales of air tickets, cargo deliveries and 
later - in networks of direct sales of tourist services). Thus, they were also interested to invest in European chains of hotels (such chains were first quite active being built near big airports and later - also at popular European resorts).

Progress in transportation and telecommunications expanded the borders of international tourist development, since it turned dozens of geographically faraway countries into popular destination points for European and American tourists. Starting from the mid-1960s European tourism market has been experiencing active interference from the side of the US hotel chains (on the territories of the United States themselves such chains were actively developing as early as the last two decades of the 19th century, thus, by the 1960s in the USA this market segment was already quite saturated) (Ushakov, 2016). The key American feature of hotel chains' development is standardization of servicing quality, absence of specific target audience and same pricing at all venues. These trends were quickly adopted by their European young competitors. The key differences of American hotel chains from the European model of hotel business were larger size of American hotels and their orientation on maximum presence in all the regions of expansion (Espenbetov et al., 2017).

In parallel to American hotels' expansion in Europe (which also meant much larger number of American tourists coming to Europe, actually), European tourism market started to experience also the expansion on the side of airlines, banks, insurance companies, etc. European hotel chains were also trying to expand in the opposite direction, however, their success on the other side of the Atlantic Ocean was much more modest: only several European hotel networks managed to open their hotels on the East Coast, in such large cities as New York, Boston, Philadelphia, and New Orleans. On the other hand, European hotels and other tourist businesses started to expand more actively in the direction of developing countries, mostly because vacations in these countries became more accessible during the 1980s (Bradley et al., 1998). Therefore, European hotels started to be present in many locations around the Middle East, North Africa, and later also in South-East Asia and Eastern Europe, gradually reaching post-Soviet countries too. On this direction of geographical expansion, American hotels were usually the ones to follow European chains (Mukanov et al., 2018).

Tour operating and agent sectors of tourism businesses became subject to active transnationalization only in the middle of the 1980s. During the same period of time transport and communications became developed enough and services became internationalized enough so that to turn international tourism into a truly global phenomenon of massive nature. By incomes and profits, international tourism has finally outstripped the automobile sector, textiles and even oil and gas. Tour operators thus became quite attractive objects for international investments. In many cases tour operators were merged with financial institutions to form holders and thus getting better access to financial resources of developed economies. The largest brands were becoming stronger at regional tourist markets. While franchising schemes were getting more and more popular, especially in the context of agents' and tour operators' work. Clients became more loyal to a particular grand, and this was actually the major reward from transnationalization of tourist business.

Early 1990s witnessed the unification of strategic management over hotel chains, airlines, tour operators and agent networks. Thus, a new network structure of tourist transnational corporations (TNCs) was gradually formed. This newer structure was already able to manage much more efficiently multiple popular brands within the common tourist market with its truly enormous material and technical base. Moreover, many tourist TNCs switched from the strategy of related diversification to the strategy of non-related diversification: they started to intrude and invest quite actively into ship-building, agriculture, aviation, high-tech sectors, retail trade, media and cinema businesses, etc. On the background of the ongoing internal restructuring of large tourist businesses which was taking place mostly through mergers and acquisitions, corporations were almost forced to impose their presence throughout the world and all economic sectors, thus expanding their network structures on newer and newer tourist destinations and other spheres of doing business. Traditionally, the strongest positions in terms of M\&As belong to the tourist transnational corporations of the USA, and the EU. Japan, despite its quite impressive economic growth overall, is not on the list due to this country's very late inclusion into the world tourist production processes (Kulakhmetova et al., 2018a).

Due to geographical remoteness and specificity of Japanese mentality and lifestyle, this nation began to travel with tourist purposes relatively recently. At the same time, Japan itself, as a tourist destination, is not that popular, as compared to many other destinations in Asia, due to expensive prices and also because tourist infrastructure in this country is not that developed and adapted for international visitors (Savchuk, 2002). More active outbound tourism from Japan attracted more attention to the internal tourist market of this country, especially among American and European tourism-related corporations. Their quick expansion onto Japanese market was another factor contributing to slow formation and development of Japanese tourist TNCs. Intensive processes of mergers and acquisitions at the world tourist market today confirms that contemporary tourism sector, despite its 50-year delay in transnationalization participation, has already caught up with most of industrial and technological sectors by all vital economic indicators. Therefore, world tourism today is no less attractive for large investors and international investment projects (Kulakhmetova et al., 2018b).

\section{Previous Generations of Tourist TNCs: Their CVs and Obituaries}

Outlining comprehensively the full history of tourism business transnationalization we can determine the key historic stages in tourist TNCs' development, or their generations. These generations differ between each other by several significant features, such as the key production activity, the sources of financing, directions in the course of integration, the structure of the sector and its role at world markets. Activities of the first generation of tourist TNCs was primarily related to transnationalization of the hotel businesses and the emergence of first international chains of hotels. This was followed by transnationalization of transportation which started in the subsectors of railway and air transport (Wilkins, 1992). In some cases, both hotel and transport businesses managed to move to the transnational level of management rather independently, without any financial inflows from outside, that is, from more developed types of activities (Hilton hotels' chain is a good example in this regard). In other cases, both hotels and airlines reached transnational level only within vertically integrated business structures. In this case, both hotels and international transport companies were additional, non-core type of activity, e.g., for large banks, automobile holdings, retail networks, etc. Historically speaking, the first generation of tourist TNCs covered the period between 1950s and 1970s. The key features of this period were small share of international tourist exchanges and insufficient economic liberalization on the global scale. First tourist TNCs had rather limited geographical presence, and the zones of this presence were quite strictly either European, or American (the latter included both US and Canada). Geographical expansion on the markets of third countries was rather limited since international tourists flows during those days were concentrated on a few popular destinations only, and international tourism overall was hardly ever intercontinental. Besides, tourism development in third countries was an enormously expensive business since many countries had barely any tourist infrastructure (hotels, roads, transport schedule, etc). Moreover, international (and especially intercontinental) tourism was often hindered by enormous differences between the nations - cultural, economic, social, religious, etc.

At the regional markets of Europe and North American first hotel chains and international transport companies were struggling in quite severe competitive fight, often trying to use the transnationaization factor to increase their overall sales' volume and thus reach monopoly. The choice of a direction for further expansion was predetermined not as much by the volume of expected costs (which was nearly always the case with first TNCs in agriculture or industrial production) but by the potential opportunities to sell services, and the latter was often dependent on tourism idea development and popularity and also on population mobility in general. 
Hotel chains of the first generation were forced to overcome quite high entry barriers in new countries of their expansion due to the necessity, first of all, to build brand new hotel enterprises on literary empty grounds, moreover, they had to provide all necessary infrastructure for themselves. Since this first-generation transnationalization was so expensive, hotel chains soon became the frequent clients of all possible financial structures, since they were forced to initiate new investment projects one after another (Ushakov et al., 2017). For the same reasons, those hotel chains which were belonging to automobile concerns or retails networks, found themselves in a much more convenient and easy situation since their "parents" (for example, as in the cases of "Le Meridien", or "Sheraton") were establishing own hotel chains to reach synergy effect due to the fact that both core business and auxiliary one often had a lot of same clients (thus, their client platform became only stronger). Additional synergy was reached in these cases also due to common methods of management, similar technologies in use, etc. Many industrial and especially trade corporations today are stating that during those times they somehow managed to anticipate the future tourism boom, thus, they foresaw how tourist business development could strengthen their overall stability. This was especially the case for retail trade companies since both trade and tourist services belong to the same servicing sector, thus, synergy from merging activities is higher. However, within this first-generation TNCs tour operating business and tourist agency were present only as a minor, additional component, aimed to take care of clients visiting hotels or using the services of an inside transport company. For example, many hotel chains of those times were offering their own booking services, which covered not only hotels inside the same chain but also transport tickets. Airlines were offering additionally their rooms in certain hotels (mostly inside or nearby the largest airports of Europe and the US). Since in the middle of the 20th century mass tourism was yet to emerge - there were no all-inclusive tours, or the so-called packages. Moreover, destinations for this mass tourism appeared on the geographical map of the world much later.

The key feature of the tourist corporations of the second type is much stronger role of tour operating and tour agents. The "glory hour" of operators and agents started in the early 1970s (and lasted actually not an hour, but 15-20 years) (Ushakov et al., 2017). The key precondition for the emergence and quick development of these second-generation tourism TNCs was rapid development of mass tourism as well as expansion of geographical borders in tourism. Due to significant improvements in transportation means (especially in the subsector of aircraft) as well as progress in communications, many once exotic destinations have become easily accessible for a mass tourist. First of all, these were the countries of the Middle East and Northern Africa (for the Europeans), and also the Caribbean area and South-East Asia (for tourists from the US and Canada). The tourist product from the third-world countries was much cheaper than European or American one. Also, getting to such a faraway destination point became much cheaper since aviation was developing quite intensively in terms of technologies used and in parallel to this technological competition was also developing quite successfully, thus contributing to prices' gradual fall. All these factors provoked truly colossal growth of tourist demand for these destinations in developed countries.

Still, these newer destinations had their problems: information on vacationing and conditions in these countries was very limited and not always trustworthy; tourists demanded certain guarantees for services' provision in full and their quality level, etc. Therefore, this newer market had a truly urgent demand for tour operating and tourist agents' intrusion. Tourist firms working with these new destinations began to emerge in nearly all regions of Europe and America. With fairly equal rate they were accumulating both experience in organization of such trips and financial funds from these trips. Stable market demand stimulates wider spread of risky schemes in relations between tour operators and suppliers of tourist services (this is especially relevant in relations with airlines and hotel chains). In the middle of the 1980s tour operators and tourist agents were already not some sort of invisible intermediaries but the most valuable clients for many suppliers of tourist services. Active sales in the segments of tour operators and agents soon became an indirect, but still very trustworthy guarantee for the financial wellbeing of transnational hotel and transport companies. Changed conditions require from all tourist TNCs to have own and recognizable enough brand as well as well-developed agent network. Development of both requires quite significant investments which go even higher than investments in hotel and transport networks' development.

This trend has been also stimulated by active distribution of franchising schemes in hotel business. Third countries - especially Turkey, Cyprus, Tunisia, Thailand, some of the Caribbean - have invested quite heavily (though via their private investors mostly) in the development of tourist infrastructure, construction of hotels, also building roads and providing all sorts of leisure for future tourists - from catering to entertainment (Andreeva and Ushakov, 2016). For many developing countries these were the times when international tourism became an economic priority of the state level. Expansion of hotel chains at the markets of third countries was not restrained anymore by the necessity to invest heavily, again, thanks to franchising schemes: it was enough to find an eager franchisee among the newly built hotels and make sure their internal standards comply with corporate standards of tourists' servicing.

From those times the geographical difference has been forming between brand popularity and the presence of hotels in a partic ular country. Already in 1985, the number of the hotels which were nominal members of a certain hotel chain on the franchising conditions was 6,7 times higher than the number of the hotels in fact owned by the same hotel chain. Franchising also contributed to further globalization of large hotel chains: today you can book choosing between nearly identical set of hotels in all countries of the world where European and American tourists are travelling. Typical for the first generation of tourist TNCs conditions of expansion which assumed buying a hotel directly or building it from the ground level became not typical anymore: starting from late 1970s already this scheme was used only in relation to the poorest countries of the world which did not have enough own funds to construct these hotels and comply to a certain level and standards of quality. Therefore, hotel chains were now freed from previously mandatory investments into the hotel industry. Freed financial funds became to be spent to increase the performance efficiency of tour operating companies and age nt networks, both being managed by hotel chains and transport TNCs. These processes have their internal logic, at least from the standpoint of consumer demand and market nature of enterprises' functioning (Ushakov et al., 2017). Tourist TNCs started developing in the direction of tourists' interests, since the latter were their end consumers. Taking into account the growing demand for tourist product as a complex of coordinated (in time, location and order) tourist services, emergence and further rapid growth of tour operators as well as their quick transition to being the core business of tourist TNCs seem to be quite understandable.

Besides restructuring of interrelations inside corporations, tourist TNCs of the second generation turned to the production of various additional services for their clients - tourists using the services within their vertically integrated businesses. Thus, tourist TNCs got their first car rentals, specialized media, own productions of tourist-related commodities (suitcases and travel bags, photocamera accessories, etc.). Logically enough, as the continuation of the same trend, with time, tourist TNCs also started providing their own insurance and other financial services (including travel loans, travel checks, etc.).

\section{The Third and the Fourth Generations of TNCs as Macrofactors of the Tourism Sector}

Tourist TNCs of the third generations were already the corporations with quite explicitly dominating role of tour operating and agents' network. Moreover, large enough tour operators, which previously were present at the transnational level of business thanks to their inclusion into international hotel and transport business, became now capable enough for independent transnationalization. Transition to this new form 
of tourist TNCs became possible not only due to better financial condition of many tourist enterprises worldwide, but more due to the increased interest to this business from the side of both private and institutional investors. Early 1990s already witnessed the increased attention to the intangible resources of tour operators, including their brands, availability of constant client base, well-developed agent network. These factors guaranteed success for nearly any investment project within international tourism.

During the same 1990s tour operating became independently transnational sort of business, almost fully independent from hotel chains and transport enterprises. Now tour operators were able to set new directions and destinations and use their own tools of transnationalization to conquer new markets. Intensive development of information technologies in the same period made it possible to set sufficient connections between numerous offices worldwide along with numerous suppliers. In parallel to that, economic globalization was gradually turning to be a cultural phenomenon too, thus increasing the international cost of tourist brands manifold. Cultural globalization was also one of the major reasons for another boom in demand for mass, standardized tours, now in both developed and developing countries. These mass tours made tour operators the key player in tourism TNCs' functioning (Provalova et al., 2019).

Since late 1980s transnational tourism business stretched its expansionary tentacles also on suppliers. Motivation to increase own competitiveness on the global scale, basing on lower prices and guaranteeing good quality at the same time, stimulates larger tour operators to acquire hotel and transport companies. This means tour operators tend to demonstrate top-down (or downstream, in other words) growth. Same trend, interestingly, has been also peculiar for many transnational industrial enterprises (Movsesyan, 2001). This sort of expansion allows tour operators have minimum expenses on tourist services' production thanks to numerous extra opportunities provided by transnationalization, including transfer pricing, more efficient tax planning, business processes' optimization, etc. Moreover, exclusion of independent intermediaries (mostly suppliers) means more guarantees that tourist services will be provided timely and at the needed level of quality. Also, transnational tour operator gets additional advantages from stability growth under the conditions of multifactor dynamics of the tourist market development. To some extent, transnational tour operators could be even treated as truly independent economic agents of the global level. Tourist TNCs of the third generation had the following key distinctive features:

- they viewed the market and own competitive position on the planetary level;

- they did their research and had profound knowledge on the key competitors and the possible methods to be used in the global competitive fight;

- they were operating either on the global scale, or at least on the level of truly large regions;

- they were using a significant share from their profits on research, first of all technological one, and also on HR development and supply for all their activities;

- all their branches and representative offices were coordinated using the most advanced information technologies;

- each production within a TNC was organized in the most flexible way, its structure and methods being easily adapted to the constantly changing conditions of international production;

- all enterprises and branches are closely united within the common international network of management;

- there are integration agreements with other TNCs, also operating in the sector of tourist services' production.

Therefore, tourist TNCs of the third generation should be described, first of all, through the prism of the leading role belonging to tour operators and tour agents. Also, tour operators' expansion into the hotel businesses and transport sector should be taken into account (and this should be understood as related diversification of business activities).

Transition to yet another generation of tourist TNCs was connected with the spread of non-related diversification, which gradually became one of the key strategies of transnational companies operating in the sector in question. This non-related diversification usually meant that a parent company was buying some totally different types of businesses, with hardly any connection to tourism (Mikhailushkin and Shimko, 2005). This expansion of tourist TNCs on other types of economic activities was caused, on the one hand, by their stronger economic stand overall and their enormous financial capacities (putting it simply, they were able to sign nearly any M\&A deal, regardless the sector). On the other hand, expansion was caused by the growing independence of tourist TNCs from the world markets' fluctuations which indirectly determined the state of tourism in regions and also globally. The prominent role in all business activities of the TNCs' fourth generation belongs to banks and other financial institutions. The latter have become a mandatory element within the structure of any TNC which has international transactions, especially if this TNC plans to perform M\&A, engage in leasing, crediting or investment activities.

Become the norm when a mandatory element in the tourist TNCs are financial institutions that carry out international operations to absorb other companies or merge with them, leasing, lending and investing. In the fourth generation, tourist TNCs become active participants in numerous mergers and acquisitions, but not of the role of the object, but of the buyer. Having become global, tourist TNCs are consistently pursuing a strategy for the formation of large groups impoverishing production, trading and financial companies. But in addition to the economic alliances of large TNCs with each other, transnational global companies are strengthening cooperation with small and medium enterprises.

Tourism TNCs which have already become global are engaged in implementation of the strategy of large groups' formation. These groups unite production, trade/retail, and financial companies. Apart from having strategic economic alliances between themselves, TNCs also strive to strengthen their cooperation with small and medium-sized business, both at home and abroad. In particular, they tend to widen their networks of suppliers and providers by means of adding small firms which are quite successful when it comes to new technologies' introduction in tourism services' production. These smaller firms are often able to develop independently new types of tourist product and perform their promotion. These firms are also strong enough to maintain their own material and technical basis, etc. This multibranch network of subcontracts enables tourist TNCs free themselves from many minor (or not really financially meaningful) operations and functions, and thus - concentrate on the most prospective directions which often require significant volumes of investment too.

According to P. Drucker (1966), the leading American specialist in efficient management, the future belongs to the enterprises of medium size (from 200 to 400 employees). Such enterprises are small enough to remain flexible, and at the same time they are large enough for serious investments in own innovations and their implementation. Following roughly the same logic, tourism TNCs, in parallel to ongoing enlargement and diversification of activities, reject the idea of gigantomania in their productions. Thus, we can observe that the size of production units within a corporation tends to reduce, while specialization of these production units is getting narrower. In the opinions of Mikhailushkin and Shimko (2005), TNCs are "losing their weight", that is, they are becoming less cumbersome, at the same time, they are "developing muscles" - that is, they are becoming much stronger due to higher flexibility and better maneuverability.

This fourth generation of tourist TNCs also become active participants of numerous deals on mergers and acquisitions, noteworthy, not as objects of these deals, but as immediate buyers. These M\&As also get a new direction - not traditional downstream, as it used to be when TNCs got the right to manage their key suppliers. Now after a M\&A deal the TNC gets the right to manage new types of businesses, with their direct and immediate effect on the suppliers' performance. Consequently, TNCs themselves became the macrofactors within the external environment of the tourism sector. 


\section{CONCLUSIONS}

In the middle of the 20th century transnationalization of tourism business was caused, first of all, by the imperfections of the still forming international tourism market. Large enterprises, driven by the growth of demand for international tourist trips and functioning under the conditions of already tight competition at national markets, were forced to move to the transnational level of management with the aim to overcome the influence of such market bottlenecks as national barriers for free international trade in tourist services due to significant differences in economic, social, political, cultural, religious conditions of people's lives in different countries. Another bottleneck was related to differences between various national taxation and currency exchange regimes as well as differences in costs behind the attraction of various factors into tourist service production. Thus, the scale effect from tourist service production was seen as the means to achieve additional competitive advantages. Moreover:

- Transnationalization of tourism business started in the middle of the 20th century, thus already then with about a 50-year delay from industrial and agricultural productions.

- Among the causes for this delay we need to mention, first of all, later (than in other sectors) development of the world market, later transition of tourism into an international, then also global and mass phenomenon as well as lower investment attractiveness of foreign tourism objects due to significant potential costs of such investment projects and their narrow specialization on provision of tourist services only.

- Transnationalization of international tourism started with the emergence of hotel chains and transport companies due to the fact that these companies had (and still have) high-cost material and technical base which could have been easily resold in case of any risk.

- Foreign direct investments in the hotel business and transportation was limited for a long time, first of all, by limited opportunities for switching the specialization of tangible assets in case of an investment project's failure and its following resale.

- For the hotel and transportation sectors themselves international tourism later became an additional stimulus for further transnationalization, since tourism sector, in the middle of the $1980 \mathrm{~s}$, became a truly mass phenomenon, mainly due to wide spread of franchising mechanisms in it, which managed to lower the entry barriers at international tourism markets and also to minimize many risks related to transnational activities.

- Transnationalization of tourism business was covering primarily the most developed countries of the Western world. Inclusion of developing economies into these transnational processes took place slightly later, with more rapid development of transport and communications, and also due to the fact that intercontinental tourism became much more real for the many.

- The subsector of tour operators and agents entered the stage of transnationalization much later. This is because key assets of both operators and agents are mostly of intangible nature, while investors, including big international investors, started paying attention to intangible assets (such as brand or new advanced technologies, for example) quite later, mostly in the last two decades of the previous century.

- The current stage in transnationalization of tourism business demonstrates that the leading role already belongs to the tour operators which are financially most stable. Moreover, they have quite easy access to financial resources of the largest banks since the latter are often also very much interested in further enlargement of both tourist and hotel TNCs which often happens through mergers and acquisitions. As of today, the leading role at the world tourism market belongs to American and European tourism TNCs.

\section{REFERENCES}

Andreeva, E., \& Ushakov, D. (2016). Internal regional and demographic tourists' inflows distribution as factor of national tourism competitiveness. Actual Problem of Economics, 9, 220-227.

Bradley, M., Desai, A., \& Kim, E. (1988). Synergetic gains from corporate acquisitions and their division between the stockholders of target and acquiring firms. Journal of Financial Economics, 21(1), 3-40. https://doi.org/10.1016/0304-405X(88)90030-X

Drucker, P. (1966). The effective executive: The definitive guide to getting the right things done, Harper Business, New York.

Dunets, A.N., Vakhrushev, I.B., Sukhova, M.G., Sokolov, M.S., Utkina, K.M., \& Shichiyakh, R.A. (2019). Selection of strategic priorities for sustainable development of tourism in a mountain region: concentration of tourist infrastructure or nature-oriented tourism. Entrepreneurship and Sustainability Issues, 7(2), 1217-1229. https://doi.org/10.9770/jesi.2019.7.2(29)

Espenbetov, N., Sardarov, O., Pestova, A., Ushkulakova, G., \& Imangulova, T. (2017). The characteristic features of the development of tourism in the mountainous regions of Kazakhstan. Espacios, 38(47), 1-6.

Kala, N., Abaydeldinov, Y., Furman, T., \& Ponomarev, A. (2017). The world tourism organization for countering terrorist threats. Journal of East Asia and International Law, 10(2), 549-550. https://doi.org/10.14330/jeail.2017.10.2.11

Karmanovskaya, N.V., Smirnova, A.T., Litovchenko, V.I., \& Efa, S.G. (2020). Automated systems of ecological control in Norilsk. IOP Conference Series: Materials Science and Engineering, 734(1), Article number 012175.

Kulakhmetova, G.A., Hnatkovych, O.D., Rusnak, A.V., \& Shcherbakova, N.A. (2018a). The way to the leading positions in world tourism: Case study of Kazakhstan. Journal of Environmental Management and Tourism, 9(6), 1289-1295. https://doi.org/10.14505/jemt.v9.6(30).18

Kulakhmetova, G.A., Shcherbakova, N.A., \& Tsypko, V.V. (2018b). Modeling and optimization of socio-economic aspects for the development of tourism. Journal of Environmental Management and Tourism, 9(8), 1696-1705. https://doi.org/10.14505//jemt.v9.8(32).08

Mikhailushkin, A., \& Shimko, P. (2005). Economy of transnational company, Vysshaya Shkola, Moscow.

Movsesyan, A. (2001). Transnationalization in the world economy, Financial Academy under the Russia Government, Moscow.

Mukanov, A., Saduov, A., Akbayev, Y., Dulatbekova, Z., Ospanova, A., Selezneva, I., Madiyarova, E., \& Jempeissova, G. (2018). Composing of scenarios development in strategic planning. Journal of Environmental Management and Tourism, 9(3), 491-500. https://doi.org/10.14505//jemt.v9.3(27).09

Provalova, E.V., Lukiyanova, M.N., Skrobotova, O.V., \& Ivanova, R.M. (2019). Prospects for the development of ecological tourism in specially protected natural areas of the Ulyanovsk Region. Journal of Environmental Management and Tourism, 10(4), 809-818. https://doi.org/10.14505/jemt.v10.4(36).11

Rudyk, N. (2000). Market of corporative control in the Russian Federation. Finansist, 11, 15-27.

Savchuk, S. (2002). Analysis of basic motives of merges and acquisitions. Management in Russia and Abroad, 5, 34-41.

Sayabaev, K., Nurgaliyeva, Z., Temirova, A., Kasenova, A., Dzhamburbaeva, M., Zhangirova, R., Sadvokasova, K., Kemel, M., Kodasheva, G., Shamuratova, N., \& Zhansagimova, A. (2016). Finance, franchise and their impact on tourism. Journal of Internet Banking and Commerce, 21(3), 229.

Tulbayeva, A., Abdikarimova, M., Ganitaev, M., Imangulova, T., \& Pestova, A. (2017). Optimization problems distribution of investments for the implementation strategy of domestic tourism in Kazakhstan. Espacios, 38(47), 1-7.

Ushakov, D. (2016). Dynamics of international economic relationships in the global context of innovative modernization. International Journal of Environmental and Science Education, 18, 12937-12945.

Ushakov, D., Elokhova, I., \& Kozonogova, E. (2017). Post industrialization prospects in the dynamics of socioeconomic transformations: Cluster approach. International Journal of Ecological Economics and Statistics, 38(2), 23-32.

Wilkins, M. (1992). The growth of multinationals, Harper Business, New York. 